\title{
The crucial and contested global public good: principles and goals in global internet governance
}

\author{
Hans Morten Haugen \\ Faculty of Theology, Diaconia and Leadership Studies, VID Specialized University, Stavanger, \\ Norway, hans.morten.haugen@vid.no
}

Published on 28 Jan 2020 | DOI: 10.14763/2020.1.1447

\begin{abstract}
Demands for a more democratic, transparent and accountable management of the internet were strong when preparing for the World Summit on the Information Society Review (WSIS Review), held in 2015. Partly in response to criticism, the United States initiated a process for transferring responsibility for domain names from the United States to the Internet Corporation for Assigned Names and Numbers (ICANN). Increased accountability was among the key motivations for this change. ICANN practices what have subsequently been termed multi-stakeholder governance. This article finds that this form of governance is preferable to an intergovernmental governance model both in terms of transparency and accountability.
\end{abstract}

Keywords: Global internet governance, Internet Assigned Numbers Authority (IANA), Internet Corporation for Assigned Names and Numbers (ICANN), Internet Governance Forum (IGF), World Summit on the Information Society (WSIS)

\section{Article information}

Received: 31 Jan 2019 Reviewed: 05 Sep 2019 Published: 28 Jan 2020

Licence: Creative Commons Attribution 3.0 Germany

Competing interests: The author has declared that no competing interests exist that have influenced the text.

\section{URL:}

http://policyreview.info/articles/analysis/crucial-and-contested-global-public-good-principles-and-goa ls-global-internet

Citation: Haugen, H. M. (2020). The crucial and contested global public good: principles and goals in global internet governance. Internet Policy Review, 9(1). DOI: 10.14763/2020.1.1447

\section{INTRODUCTION}

Barack Obama stated in 2015, in response to EU criticism over US dominance over the internet: "We have owned the Internet. Our companies have created it, expanded it, perfected it..." (The Verge, 2015). Despite this, the US administration has completed a process of transferring its former stewardship responsibility over a body called IANA (Internet Assigned Numbers Authority), formally a department within the larger ICANN (Internet Corporation for Assigned 
Names and Numbers) to ICANN itself (Raustiala, 2017).

ICANN is perhaps the most prominent example of a multistakeholder governance model, as opposed to an intergovernmental governance model. The term multistakeholder was not applied to characterise ICANN from its inception in 1998, as will be explained below. The advocacy coalition framework (ACF), developed by Sabatier and Jenkins-Smith (1993) can illuminate the possibilities and challenges that the multistakeholder governance structure (multistakeholderism; see Raymond and DeNardis, 2015) faces, from various actors. According to one author, the complexities and power asymmetries involved in the management of ICANN imply that an alleged "multiple accountabilities disorder" (Koppell, 2005) applies.

Civil society organisations (CSOs) believe that the digital divide can be overcome by an internationalisation of internet governance (Weber, 2009, p. 164). Internationalisation is understood as a situation where several states influence how the internet is governed. Calls for change in the global internet governance are frequently heard, as will be seen below, most notably at a meeting hosted by Brazil in 2014 (NETmundial, 2014, p. 6).

The domain name system (DNS) and root server administration are crucial elements of global internet governance, which are exercised by ICANN and IANA, and its more detailed structure will be clarified below. The DNS falls under the management of the Transmission Control Protocol and Internet Protocol (TCP/IP) suite (Bygrave, 2015a, pp. 10-16).

Internet governance is, however, a wider term encompassing many policy areas (Council of Europe, 2015; Council of Europe, 2011; DeNardis, 2013a) and is defined as:

\section{the development and application by governments, the private sector and civil society, in their respective roles, of shared principles, norms, rules, decision-making procedures, and programmes that shape the evolution and use of the Internet (United Nations General Assembly, 2006, para. 34).}

By highlighting principles, norms, rules and procedures, the United Nations (UN) implicitly says that internet governance must be more than a mere technical exercise. This definition is wide (Bygrave, 2015a, p. 15), but so is the range of internet governance tasks (Raymond and DeNardis, 2015, pp. 570-572; listing 43 different tasks). There are no international treaties regulating internet governance, and the sources that are applied in the article are (i) declarations from UN summits, (ii) outcomes from the ICANN processes in recent years, (iii) statements from the US government, and (iv) documents from both non-governmental and intergovernmental processes. Even if it is fair to state that the way in which ICANN operates has sidelined the UN, UN sources can be relevant, conceptually and in terms of identifying new approaches (Padovani et al., 2010, p. 367, referring to the 2003 World Summit on the Information Society (UN WSIS)). The same authors found, however, that governmental actors build on a narrower view of which are the relevant internet actors, while non-governmental organisations have a broader understanding of such actors and tend to operate with a more complex terminology, often embedded in human rights. Nevertheless, I will refer to the UN when identifying the principles and goals, acknowledging other lists (Pettrachin, 2018, p. 341; Padovani et al., 2010, p. 365; Mueller et al., 2007, pp. 243-250).

This article emphasises the internet governance principles, because these are in greatest need for clarification and because they provide direction for the norms, rules and procedures. The UN 
has called for the "development of globally-applicable principles..." [UN General Assembly, 2006, para. 70; UN Working Group on Internet Governance (UN WGIG), 2005, para. 13(a)]. No agreement has emerged, however, as to what these principles are. Moreover, there will be an emphasis on goals and the role of human rights in global internet governance, a topic promoted by Council of Europe (2019; see also Levinson and Marzouki, 2016).

The article proceeds as follows: Section 1 outlines the principles of global internet governance, including accountability. Section 2 identifies the goals that are to be ensured by internet governance. Section 3 analyses the processes within some actors in global internet governance, focusing on the International Telecommunication Union (ITU) and ICANN. Section 4 reviews reform proposals for internationalisation or globalisation of internet governance. Section 5 analyses ICANN's process to accommodate human rights concerns, developing further the critical assessment made by Appelman (2016).

The main difference between goals and principles is that goals are about the essential nature of global internet governance while principles refer to the minimum standard of conduct in decision-making relating to global internet governance.

As a premise for the argument put forth in the article, it is only by supplementing the overall principle of multistakeholder governance by other substantive principles that ICANN's overall legitimacy can be adequately strong. Weinberg (2012) understands legitimacy as being external to the organisation, more specifically the perception by relevant actors that a given organisation is an appropriate wielder of authority. Legitimacy is in this article operationalised as encompassing adequate and widely-accepted procedures for participation and accountability. Demonstrating broad-based participation by all stakeholders and mechanisms for holding the ICANN Board to account have been priorities of ICANN, when being met with criticism of neither being transparent, nor democratic or representative. ICANN had from its inception weak legitimacy, seeking to overcome this by (i) (inadequate) systems adopted from US administrative law - but without judicial review; (ii) enhanced representation (elaborated by Malcolm, 2015); and (iii) developing decision-making as consensus (Weinberg, 2000).

I have emphasised the terms accountability and participation as an operationalisation of legitimacy for two reasons. First, in the IANA transition process, the Cross Community Working Group on Enhancing ICANN Accountability (CCWG-Accountability) was established, with two "work streams": the first (WS1) related to the IANA transition process and the second (WS2) addressing accountability issues beyond this process (ICANN, 2018a, pp. 25-33; see also annexes 5-7; ICANN, 2018d). Hence, enhanced accountability and participatory processes have been identified by ICANN itself as crucial. Second, as the analysis in Section 5 will particularly show, there were attempts to embed ICANN's activities more explicitly within a human rights framework, and both accountability and participation are recognised as human rights principles.

The research question that this article seeks to answer is: Will recent measures taken by ICANN to improve its overall accountability and comply with other principles, as well as fulfilling the goals of global internet governance, improve ICANN's legitimacy and governance, and hence strengthen the multistakeholder governance model, as opposed to an intergovernmental governance model? 


\section{SECTION 1: PRINCIPLES IN GLOBAL INTERNET GOVERNANCE}

As specified above, principles are understood as the minimum requirement of appropriate conduct that must be complied within all decision-making processes. Robert Alexy refers to principles as "optimization commands" (Alexy, 2000).

The Internet Society (ISOC) has identified "fundamental Internet principles" (ISOC, 2015, pp. 2 and 7), but with the exception of openness and multistakeholderism, these principles are not further specified. A second term applied by ISOC is "key Internet principles", which encompasses openness and the multistakeholder model, as well as stability and integrity, and bottom-up processes (ISOC, 2015, p. 2). A third term applied by ISOC is "these principles", among which are accuracy, availability, and transparency (ISOC, 2015, p. 2). Hence, it is not evident if the term 'principle' has one or several meanings and how these three categories relate to each other.

Moreover, in the context of the IANA stewardship transition, ICANN presented the following "principles that were suggested": inclusive, transparent, global, accountable, multistakeholder, focused [in scope], pragmatic and evidence-based, open [to all voices], do no harm, and consensus-based (ICANN, 2014a). Some of these ten principles are merely describing the ambition of inclusive representation (global), others are not adequately distinct (pragmatic). Hence, they cannot constitute fundamental principles.

Another initiative, NETmundial, established with the purpose to challenge the US' dominant role over the internet in the aftermath of the surveillance practices revealed by WikiLeaks, distinguishes between internet governance principles and internet governance process principles (NETmundial, 2014, pp. 4-7). What NETmundial terms "principles" will in this article be referred to as goals, and what NETmundial refers to as "process principles" will in this article be referred to as principles.

In order to clarify principles for internet governance, there is a need to explore other sources. Being the most representative intergovernmental organisation, it is interesting to analyse whether the UN clarifications are helpful.

Openness, identified by ISOC as a fundamental internet principle, does not appear in the outcome document of the 2015 UN High-level Meeting (UN, 2015) reviewing the implementation of the 2003 and 2005 phases of the World Summit on the Information Society (UN WSIS).

Openness can be a term used to describe adequate internet governance processes (Redeker et al., 2018, p. 307), but the core of such processes are better captured by the term transparency, as will be explained below. Openness has been defined as "open and free communication within the internet, interoperability, standard development..." (Padovani et al., 2010, p. 373), a definition that is closer to describing the essential nature of the internet, in other terms a goal. Hence, I find that openness should rather be termed a goal, as further explained in Section 2 below, than a principle. When openness is applied in the context of describing the internet governance process - operationalised as minimum standard of conduct in decision-making - it can be applied as a principle.

The multistakeholder approach seeks to involve all stakeholders, and is a "form of participatory 
democracy that attempts to go beyond the limitations of representative democracy, while building on, and including, representative democracy" (Doria, 2013, p. 121). Five stakeholders are identified: governments, the private sector, civil society, international organisations, and technical and academic communities (UN General Assembly, 2016, para. 2); note that the latter was not listed in the UN WSIS (UN General Assembly, 2006, paras. 35-36). The UN confirms multistakeholderism as one fundamental internet principle, but does not specify its content. This is, however, done by Weber, listing nine "factors" of the multistakeholder approach, implying that this approach is seen as a meta-principle (Weber, 2013, p. 103).

A distinction can be made between a position holding that no decision on internet governance should be made except through multistakeholder bodies, and a more moderate position holding that most relevant issues should be decided by multistakeholder bodies (Hill, 2013, p. 85). While the multistakeholder approach is currently the dominant approach, it is not uncontested, as will be shown in Section 3 below.

Which other internet principles are identified? The three UN WSIS highlighted the three terms "multilateral, transparent and democratic..." (UN WSIS, 2003, para. 48; UN General Assembly, 2006, para. 29; UN General Assembly, 2016, para. 57). These three terms will be reviewed to analyse whether they qualify as a principle in global internet governance, keeping in mind that principle was defined in the introduction as minimum standard of conduct in decision-making. I will now clarify whether these three qualify for being termed principles.

Multilateral refers to involving more than two parties, and is usually applied on cooperation between states. There are obvious tensions between being multilateral and being multistakeholder. This was clearly stated by the US National Telecommunications and Information Administration (NTIA) when the so-called "stewardship transition" of IANA to ICANN was launched in 2014: “...NTIA will not accept a proposal that replaces the NTIA role with a government-led or an inter-governmental organization solution" (NTIA, 2014). The US authorities are exercising a form of veto power to prevent any interference with the ICANN's governance model. Hence, under the present system, multilateralism cannot be termed a principle in global internet governance, even if states are represented in the ICANN structure, through the Government Advisory Committee (GAC).

Transparency relates essentially to how to facilitate participation in the decision-making process. Hence, transparency, being an overall UN human rights principle (UN Development Group, 2004), it can qualify as an internet principle. In its early years, ICANN was ordered to enhance its transparency procedures (ICANN, 2002; for a critical analysis of the process establishing ICANN, see Weinberg, 2000).

Being democratic is to have procedures for installing and replacing decision-making bodies, based on free elections. The current multistakeholder model by ICANN - referring to "groups" (ICANN, 2012) and not "stakeholders" - is not adequately democratic (Gurstein, 2014). While I agree with Gurstein that ICANN is not adequately democratic, and with Malcolm (2008, p. 291) that consensual decision-making describes ICANN better than democratic decision-making, it must be asked whether an international governance system representing such a diversity can ever be adequately democratic, in line with the definition above. ICANN has rather sought the representation of all relevant stakeholders, and to improve its accountability mechanisms. Hence, multistakeholderism is arguably the most inclusive decision-making that ICANN can provide (see: DeNardis, 2013b), and it is difficult to include democracy as a principle in internet governance. 
This lack of acknowledgment of democracy as a principle in global internet governance cannot, however, be seen as a lack of recognition of democratic decision-making as an essential value. Bygrave emphasises that the success of the internet is the fact that it "developed in open and democratic decisional cultures..." (Bygrave, 2009, p. 6). Mueller holds, however, that the US control over the DNS has not secured freedom of expression (Mueller, 2016), and that states through the Government Advisory Committee (GAC) of ICANN have too much influence in ICANN (Mueller, 2015; Mueller, 2010, pp. 240-251), as will be explained in Section 3 below.

Hence, only one of the principles proposed by the UN can actually be considered to be a relevant principle for decision-making as ICANN works today. The two principles we are left with from these sources are multistakeholderism and transparency. Both are explicitly linked to participation, and can be justified by the theory of reflexive law, which emphasises norm development through participatory processes, rather than through instructions by top-down regulation (De Schutter and Lenoble, 2010). Other labels are proposed, such as "hybrid intergovernmental-private administration" (Ruotolo, 2017, p. 162), characterised by active involvement and commitment by corporations and civil society organisations.

Multistakeholderism and transparency specify requirements of an adequate decision-making process. However, accountability - having one's conduct assessed in relation to externally set norms, with possibilities for administrative or legal sanctions in cases of non-compliance (Koppell, 2005, p. 96) - is missing from the list. The principle of accountability for companies has gained increased recognition recently, constituting one of four elements of due diligence (OECD, 2011, p. 23), as elaborated by the UN Guiding Principles (UNGP) (UN Human Rights Council, 2011).

The principle of accountability has been specified and operationalised by ICANN (2018a; ICANN, 2018b, Section 4.6(b)(i); see also ICANN, 2014a and NTIA, 2016). In accordance with its bylaws, ICANN mandated in early 2019 its third Accountability and Transparency Review Team (ATRT). While an ICANN ombudsman has been in operation since 2004 (ICANN, 2017e), the clause on reconsideration in ICANN's bylaws (ICANN, 2018b, Section 4.2) provides the formal procedure for requesting the ICANN Board to reconsider an action or inaction. Moreover, ICANN has been subject to legal proceedings (ICANN, 2002; ICANN, 2018c). Hence, while internal accountability mechanisms have been strengthened, the US government through NTIA will not allow ICANN to act contrary to US interests, and courts in various countries do provide a form of external accountability (ICANN, 2018c). As a result of the processes relating to the IANA transition, the earlier criticism of ICANN from the global community of internet users, through the At-Large Advisory Committee (ALAC) and the considerably wider At-Large Summit (ATLAS) (ICANN, 2013, p. 53; ICANN, 2009, p. 3), has gradually been replaced with stronger concerns for the positions of states (ICANN, 2014b; p. 2; Bygrave, 2015b). The third ATLAS took place at the ICANN66 meeting in November 2019.

Another group of stakeholders, the states, do recognise that existing arrangements for the Internet "have worked effectively..." (UN General Assembly, 2016, para. 55; UN General Assembly, 2006, para. 55). Hence, it is reasonable to state that the tensions over global internet governance are not primarily related to the tasks fulfilled by ICANN and IANA.

To sum up, the omission of accountability in the relevant paragraph from the UN WSIS review (UN General Assembly, 2016, para. 57; see also UN WSIS, 2003, para. 48; UN General Assembly, 2006, para. 29) cannot be read to imply that accountability is off the list of principles in global internet governance, in addition to multistakeholderism and transparency. 


\section{SECTION 2: GOALS IN GLOBAL INTERNET GOVERNANCE}

We saw above that openness can be termed a goal of global internet governance. Which other goals are there? Also in this endeavour, it is considered relevant to turn to the UN, as well as other actors, with more direct roles in relevant ICANN processes. The UN has specified that "an equitable distribution of resources, facilitate access for all and ensure a stable and secure functioning of the Internet, taking into account multilingualism" as important in guiding the "international management of the Internet" (UN WSIS, 2003, para. 48).

Equitable distribution, access for all, stability and security, and accommodating diversity, being wider than merely "multilingualism", are on the face of it all relevant, but do they fulfil the criteria specified in the introduction, namely that goals relate to the essential nature of global internet governance? We will review these, starting with stability and security.

The so-called NTIA criteria include to "maintain the security, stability, and resiliency of the internet DNS [domain name system]" (NTIA, 2014; see also IANA Stewardship Transition Coordination Group, 2015, p. 7). Stable and secure functioning is a prerequisite for the internet per se, and therefore to be understood as a goal for global internet governance.

According to the UN, "equitable distribution of resources" is an important objective in the realm of the global information society overall (UN General Assembly, 2016, para. 1). Can it be termed a goal in internet governance, being about providing internet connections for all that have an adequate speed - or connectivity? While enhanced distribution of resources might be a result of the enhanced connectivity for persons in remote regions and rural areas, it seems difficult to term equitable distribution as an overarching goal in global internet governance.

What then about "access for all"? Access can encompass four dimensions: (i) economic access affordability; (ii) universal access - internet access within a reasonable distance from one's home; (iii) universal service - having internet in homes; and (iv) universal design - also termed usability, in accordance with Articles 9 and 21 of the Convention on the Rights of Persons with Disabilities (G3ict, The Global Initiative for Inclusive ICTs, 2009).

A fifth dimension of access is (v) network neutrality, implying that no-one shall be unjustifiably or arbitrarily excluded from accessing the internet (European Union, 2015; Scott et al., 2015). This was emphasised in the revision in for instance the French law to protect intellectual property on the internet (HADOPI), that from 2013 no longer permits the suspension of internet access for repeated infringers (for a critical analysis of the previous practice, see Jamart, 2013). Hence, it seems justified to term "access for all" an overarching goal. In essence, however, it is difficult to see any major difference between access for all and an open internet, as specified by Padovani et al., as outlined in Section 1 (2010, p. 373). This goal is better referred as open and accessible for all.

Finally, "multilingualization" has been specified as a critical internet resource [UN WGIG, 2005, para 13(a)]. A review of ICANN's At-Large system criticised ICANN's reliance on English, as this "may be alienating for many" (ITEMS International, 2017, p. 85), and accommodating diversity has been emphasised in the CCWG-Accountability WS2 (ICANN, 2018a, pp. 18-20 and Annex 1). Hence, while maintaining the unity of global internet, the actual internet use must encompass diversity. 
Hence, stability and security of the DNS, open and accessible for all, and unity and diversity are important for global internet governance; these can therefore be termed goals.

In addition, there are "many cross-cutting international public policy issues that ... have not been adequately addressed" (UN General Assembly, 2016, para. 56; see also Global Commission on Internet Governance (GCIG), 2016): (i) information and communication technology (ICT) for development; (ii) human rights (ICANN, 2017a), such as privacy and safety for users; and (iii) confidence and security in ICT, including fighting cybercrime.

These "policy issues" will be reviewed here, in order to identify whether they have content that would imply that they qualify as goals in global internet governance.

As with the brief review of distribution above, it seems reasonable to state that notwithstanding the quality and type of infrastructure - positive socio-economic development is most likely a result of enhanced connectivity and access, and cannot be specified as a goal that is distinct from enhanced connectivity and access.

Human rights safety issues will be further analysed in Sections 4 and 5 below, but it must be considered uncontroversial to identify safety for internet users in order to protect the right to private life as constituting an overall goal in global internet governance.

The last policy issue identified by the UN WSIS was security, which must be understood to include international security. Wider than national security, the mutual survival and safety of people is at the core of international security. Specifically concerning international security, mandates and members for the United Nations Group of Governmental Experts on Developments in the Field of Information and Telecommunications in the Context of International Security (UN GGE) has been established five times, first in 2004 (UN General Assembly, 2003, para. 4), and most recently in 2015 (UN General Assembly, 2015, para. 5; for reports, see UN GGE, 2015; UN GGE, 2013; and UN GGE, 2010). The most recently established UN GGE failed to reach consensus during its last session in 2017 (UN Secretary-General 2017, para. 5), but a new initiative is launched (UN General Assembly, 2019).

This implies that it is reasonable to add safety and security to the list of overarching goals of internet governance.

In summary, four overarching goals that apply to internet governance can be identified: security and stability of the DNS; open and accessible for all; diversity and unity; and safety and security for all. By choosing the term all, this corresponds with the UN approach, implying that all are in principle equal to enjoy the benefits of the internet, in line with a global public goods approach. Raymond (2013) finds, however, that a more precise term is nested club good, as internet is not characterised by equal enjoyment by all. In order to proceed in the analysis of how these four goals are promoted, as these are all relevant for analysing ICANN's legitimacy, there is a need to have more insight into the relevant actors.

\section{SECTION 3: GLOBAL INTERNET GOVERNANCE ACTORS}

ICANN was established as a private company in 1998, and the US government assigned the governmental responsibility to NTIA (US Government, 1998; Bygrave, 2015a, pp. 59-77; Cogburn 2016, pp. 33-37). The purpose of the establishment of ICANN in 1998 was a "privatization" of the DNS (US Government, 1998; see also Padovani and Santaniello, 2018, p. 
295, adding "commercialization"). Privatisation seems on the face of it to be contrary to the multistakeholder approach, as the latter seeks to allow different stakeholders to exert certain influence. Nevertheless, the term privatisation process was reiterated by US authorities in the IANA transition process (NTIA, 2016). Despite this insensitive choice of terms, ICANN has recently adopted mechanisms that have strengthened the multistakeholder approach.

It is relevant to note that in 1998 and all subsequent years, the ITU was sidelined. While a full review of all relevant intergovernmental processes relating to the internet falls outside the scope of this article, I will briefly analyse two: the EU initiative before the second session of the UN WSIS in 2005 and the attempts of enhancing the role of the ITU in global internet governance before and during the 2012 World Conference on Information Technology (WCIT).

A wide-reaching proposal for changing global internet governance was made by the EU in the process leading up to the UN WSIS in 2005, proposing to establish a Forum to provide for "an international government involvement at the level of principles over ... naming, numbering and addressing-related matters...” (European Union, 2005, p. 1). It was emphasised that this Forum should focus on "principle issues ..., excluding any involvement in the day-to-day operations..." (European Union, 2005, p. 1). The EU's motivations had few references to the multistakeholder approach, and the term multistakeholder was introduced in the report of the UN WGIG, established in 2003, and dissolved after submitting its report in 2005 (UN WGIG, 2005). In the report from the 2005 UN WSIS, the term multistakeholder is applied more than 30 times (UN General Assembly, 2006).

Moving to the 2012 WCIT, a proposal from the Russian Federation (Russia) read:

Member States shall have equal rights to manage the Internet, including in regard to the allotment, assignment and reclamation of Internet numbering, naming, addressing and identification resources and to support for the operation and development of basic Internet infrastructure (ITU, 2012a, p. 99).

At the WCIT, certain coalitions of states attempted to include internet governance in the ITU's International Telecommunication Regulations (ITRs; which entered into force in 2015). One alliance led by Russia and China sought intergovernmental control of the internet based on their concept of "information security" (Jamart, 2013, p. 60); another alliance, with India, Brazil and South Africa promoted a UN-embedded "Council on Internet-Related Policies" (Chenou and Radu, 2013, p. 11; see also Cogburn, 2016, pp. 40-42). This proposed Council is basically in line with a Global Internet Council (GIC) as proposed by the UN WGIG (UN WGIG, 2005, paras. 5256), specifying that "ICANN will be accountable to GIC" (UN WGIG, 2005, para. 54). Interestingly, there are no references to internet in the ITRs, only in Resolution 3 of the WCIT, on "the development of broadband and the multistakeholder model of the Internet..." (ITU, 2012b, p. 20).

Hence, the EU 2005 proposals and the WCIT initiatives in 2012 illustrate the dissatisfaction with the US-led, ICANN-administered global internet governance.

The rest of this section will focus on ICANN, where the US control over the DNS implied that the global "legitimacy of ICANN was fragile from the start..." (Radu and Chenou, 2013, p. 6), and Mueller reminds readers that the NTIA role in relation to IANA was meant to last for two years, but lasted 18 years (Mueller, 2015, p. 3). As seen above, legitimacy is operationalised as 
encompassing adequate and widely-accepted procedures for participation and accountability.

A full review of recent ICANN bodies and activities is not possible, but it is relevant to identify the strategies of ICANN's so-called supporting organisations (SO; having two representatives in the ICANN Board; see ICANN, 2018b, art. 9-11) and some of its advisory committees (AC). The three SOs and two of the ACs, ALAC and GAC, were provided a mechanism in 2017, termed Empowered Community (Section 6 of ICANN's bylaws; ICANN, 2018b), with a mandate that extends to "Recall the entire Board" [ICANN, 2018b, Section 6.2(a)(ii)].

ICANN's external outreach is, however, still inadequate. A recommendation on better "cooperative outreach" (ITEMS International, 2017, p. 43; see also ICANN, 2014c, p. 3), was not supported by the Generic Names Supporting Organization's (GNSO) and two of its constituencies: the Intellectual Property Constituency (IPC) and the Business Constituency (BC) (ITEMS International, 2017, p. 43).

Regarding the ACs, interesting differences appear. ALAC is represented in the ICANN Board and can influence the composition of the Board by nominating one-third of the members of the Nomination Committee.

GAC is represented on the Board by a liaison without voting rights, but has a possibility to influence ICANN priorities in more subtle ways. Under the revised ICANN bylaws, the ICANN Board must "state the reason why it decided not to follow..." the GAC's advice, obliging the Board and the GAC to enter into an efficient process "to find a mutually acceptable solution" [ICANN, 2018b, Section 12(a)(x)]. This implies increased power to governments within ICANN, which comes in addition to the influence GAC has as a part of the Empowered Community.

\section{SECTION 4: OTHER GLOBAL INTERNET GOVERNANCE REFORM PROPOSALS}

The civil society at the UN 2005 made five demands for reforms of global internet governance, the first concerning ICANN's accountability to its global stakeholders, that was analysed above. The other four are: (i) creating an Internet Governance Forum (IGF); (ii) negotiating a convention on internet governance and universal human rights; (iii) ensuring that internet access is universal and affordable; and (iv) promoting capacity building in developing countries and increasing their participation (Association for Progressive Communications, 2005). These four will be analysed below, as these are all relevant to answer the research question, on which principles and goals the ICANN's internet governance model accommodate, so that ICANN's legitimacy is enhanced.

The IGF has met annually since 2006, with a mandate that encompasses "capacity building..." (UN General Assembly, 2006, subpara. 72(h)), as well as "enhanced cooperation..." (UN General Assembly, 2006, para. 69). This mandate relates to dialogue and deliberations concerning internet policy (Raymond and DeNardis, 2015, p. 587; for a broader analysis of IGF, see Malcolm, 2008). The UN Secretary-General António Guterres established the High-level Panel on Digital Cooperation (UN Secretary-General, 2018a), and later in the same year attended - as the first UN Secretary-General - the IGF (UN, 2018). Earlier efforts of strengthening the IGF have not been successful (Hill, 2018; UN General Assembly, 2016, para. 65; UN General Assembly, 2013). The speech by France's President Macron to the 2018 IGF, based on his assertion that "the Internet we take for granted is under threat" (Macron, 2018) was further 
specified in the context of internet governance, outlining two opposites, between "complete selfmanagement, without governance, and [...] a compartmented Internet, entirely monitored by strong and authoritarian states" (Macron, 2018). While the first model was preferred by Macron, he also specified that this model implies that those deciding are not democratically elected; hence "I don't want to hand over all my decisions to them, and that is not my contract with France's citizens" (Macron, 2018). While these concerns have been commonplace in global internet governance discussions for a number of years, the fact that they are expressed by a head of a relatively strong state does not necessarily make it likely that the concerns will translate into new global internet governance policies.

On internet and human rights, there has been no specific convention, but several documents (Pettrachin, 2018 - reviewing 58 documents; Redeker et al. 2018 - reviewing 32 documents). Existing human rights treaties include provisions that obviously are relevant for internet activities, and space does not allow for a deeper discussion, but human rights processes within ICANN will be analysed in greater detail below.

On accessibility and affordability, there is relatively little progress to report on. The UN Global Alliance for Information and Communication Technologies and Development, launched in 2006, soon imploded. A Global Digital Solidarity Fund was launched in 2005 (ITU, 2005), but dissolved in 2009. In 2007, the Leading Group on Innovative Financing for Development (formerly known as Leading Group on Solidarity Levies to Fund Development) failed in introducing a digital solidarity initiative, but has succeeded in levies on air tickets. One domain name, .coop, is however, introduced with an altruistic purpose, namely to "support the global movement by helping Cooperatives..." (DotCooperation LLC, n.d.). Nothing prevents other domain name owners from establishing similar purposes.

On participation by developing countries, the most comprehensive response was the 2013 Montevideo Statement on the Future of Internet Cooperation, adopted by the CEO and President of ICANN, together with other heads of organisations in charge of internet technical infrastructures, calling for "accelerating the globalisation of ICANN and IANA functions, towards an environment in which all stakeholders, including all governments, participate on an equal footing" (Chehadé et al., 2013, bullet 3; see also UN General Assembly, 2006, paragraph 69; for critical comments on the infrastructure-mediated governance, see Arpagian, 2016 and DeNardis, 2012). The fact that these diverse actors agreed that all governments are to participate on an equal footing in global internet governance is remarkable, as evidence demonstrates that this is not the case in practice, illustrated by the quote by Obama given at the start of the article.

The broadest alliance challenging the current global internet governance model was NETmundial, referred to in the introduction. It was initiated by Brazil as a response to the revelations that the USA had tapped communication devices, including those used by (then) President of Brazil, Dilma Rousseff. In addition to Brazil, ICANN was co-hosting the 2014 NETmundial meeting (Amoretti and Santaniello, 2016, pp. 161-163), but the subsequent NETmundial Initiative, launched by Brazil and ICANN, in addition to the World Economic Forum, lasted only until 2016. While NETmundial's terms distributed, decentralised and multistakeholder (NETmundial, 2014, p. 6) indicate an explicit distancing from a state-driven or top-down approach, many of the active states in the NETmundial were among those who pushed for greater governmental control at the 2012 WCIT (Brotman, 2015, p. 3), as seen in Section 3 above.

Multistakeholderism is a governance model that seeks to limit the power of states termed as 
sovereignists (Amoretti and Santaniello, 2016, p. 167; for the term technological autonomy; see Arpagian, 2016). The sovereignists' attempts of limiting the US influence over internet governance have been perceived as threats to the present functioning of the internet (van Schewick, 2010). A survey conducted by the Global Commission on Internet Governance showed support to multistakeholderism, while the US alone running the global internet got the lowest score (Global Commission on Internet Governance, 2016, p. 86). This corresponds to the position of some influential Western researchers on global internet governance (Bygrave, 2009, p. 7; Hubbard and Bygrave, 2009, p. 235; Mueller, 2015, pp. 240-251; DeNardis, 2014, pp. 227230). In addition to the sovereignists, the current main challenge to ICANN's present working comes from the constitutionalists (Amoretti and Santaniello, 2016, p. 167), and ICANN's response to the calls for human rights in its operative work is an issue to which we now turn.

\section{SECTION 5: ICANN AND HUMAN RIGHTS}

The most recent efforts within ICANN to accommodate human rights concerns warrant a more in-depth and updated analysis (Glen, 2018). ICANN's Articles of Incorporation specify that it is "carrying out its activities in conformity with relevant principles of international law and international conventions and applicable local law and through open and transparent processes..." (ICANN, 2016b, Section 2.III). By this formulation, human rights are implicitly encompassed.

Human rights were covered in the WS1, but were brought into WS2 even more explicitly, recommending that ICANN consider "which Human Rights conventions or other instruments, if any, should be used by ICANN in interpreting and implementing the Human Rights Bylaw", shaping relevant ICANN "policies and frameworks" (ICANN, 2016a, Annex 12, p. 7). The revision of ICANN's bylaws implies that ICANN acknowledges that it has human rights obligations, "within the scope of its Mission..." and "applicable law" [ICANN, 2018b, Section 1.2(b)(viii)], but requiring that the "framework of interpretation for human rights ("FOI-HR") is approved ...by the CCWG-Accountability as a consensus recommendation" [ICANN, 2018b, Section 27.2(a)]. A consensus was eventually reached (ICANN, 2018a, p. 21 and Annex 3, pp. 47), and by June 2018 the whole WS2 process was finalised (ICANN, 2018e).

During the process, four initiatives deserve attention: (i) ALAC proposed a Human Rights Impact Assessment and a Corporate Social Responsibility (CSR) policy for ICANN (ICANN, 2017a, para. 4); (ii) to strengthen human rights in ICANN, a Sub-Group on FOI-HR was established within the CCWG-Accountability WS2; (iii) a Cross-Community Working Party on ICANN's Corporate and Social Responsibility to Respect Human Rights (CCWP-HR) was established at ICANN52 in 2015 (Karanicolas and Kurre, 2018; see also Article 19, 2015); and (iv) a website devoted to human rights updates has been established and made accessible via ICANN's home page (ICANN, 2018f). I will explore the first two initiatives in greater detail.

The responses to the WS2's human rights proposals were mixed. Government responses to ALAC's draft FOI-HR - from Brazil, Switzerland and the UK - welcomed "widening the scope of applicability of human rights instruments within ICANN...” (ICANN, 2017b, p. 2). ICANN's ACs and SOs - including ALAC itself - were more restrictive, however, specifying that human rights implementation should be limited to ICANN's "applicable law" and "technical remit" (ICANN, 2017b, p. 2). Two stakeholder groups under GNSO understood human rights as constituting a "crippling load" for ICANN (ICANN, 2017b, p. 2). 
Despite the fact that there was no consensus on including UNGP in the FOI-HR, the Sub-Group on FOI-HR noted that certain aspects of the UNGP could guide ICANN (ICANN, 2018a, Annex 3, p. 8).

The Transparency Sub-Group of WS2 also emphasised the importance of human rights (ICANN, 2018a, pp. 33-35 and Annex 8.1). Moreover, human rights and privacy have been a concern, particularly for ALAC, in light of the EU's General Data Protection Regulation (GDPR) (ICANN, $2017 \mathrm{c}$, p. 1), resulting in a revised ICANN Procedure applying specifically to the WHOIS internet protocol (ICANN, 2017d). WHOIS is a directory service including more than 187 million domain names (Marby, 2018). Even if ALAC members were dissatisfied with ICANN's GDPR response, no further action is to be taken by the ICANN Board (ICANN, 2018g, item 28). The ICANN Procedure specifies that any registrar or registry that is subject to a WHOIS proceeding should cooperate with national governments to ensure that it "operates in conformity with domestic laws and regulations, and international law and applicable international conventions" (ICANN, 2017e, Section 1.4), a wording similar to ICANN's Articles of Incorporation (ICANN, 2016b, Section 2.III), presented above.

Hence, the revision of the bylaws has not led to any explicit recognition of the two human rights that are of primary importance for ICANN: freedom of expression and the right to privacy.

\section{CONCLUSION}

The research question asked whether recent ICANN processes have enhanced ICANN's legitimacy, operationalised as adequate and widely accepted procedures for participation and accountability, and governance (Raymond and DeNardis, 2015; Weinberg, 2000), understood as the application of shared principles, norms, rules, decision-making procedures, as well as programmes (UN General Assembly, 2006, para. 34).

ICANN has made many efforts to improve its legitimacy and decision-making system in the recent years. The question is whether this is adequate to actually enhance its overall legitimacy.

The changes within ICANN are not complying with the 2013 Montevideo Statement, made by very central players in global internet governance, calling for participation by all governments on an equal footing and for a "globalization" of internet governance (Chehadé et al., 2013, bullet 3). Neither have these ICANN reforms been substantive enough to please politicians (Macron, 2018) or courts (ICANN, 2018c). Hence, the overall legitimacy and concrete actions of ICANN will continue to be challenged, but the overall framework for global internet governance seems difficult to amend.

Nevertheless, because of the continued pressure on ICANN, ICANN will continue to reform itself. This is in line with the advocacy coalition framework (ACF; Sabatier and Jenkins-Smith, 1993) providing an advanced understanding of how subsystems, such as researchers, NGOs and intergovernmental relations, contribute to policy shifts in complex organisations. The article has demonstrated that ICANN is a most relevant case to understand how the various subsystems operate, and five SOs and ACs have increased power within the ICANN structure, through the Empowered Community. Moreover, GAC has enhanced its influence even more, by requiring the ICANN Board to state why GAC's advice was not followed, and asking for a dialogue in order to find a mutually acceptable solution. While this led to a strengthening of states within ICANN, it is justified to state that there has only been a partial recognition of human rights by ICANN. 
Hence, both sovereignists and constitutionalists will continue to challenge ICANN.

Koppell's (2005) three "manifestations" of a multiple accountabilities disorder - inadequate responsiveness, responsibility and controllability in different combinations - have, however, been mitigated in ICANN's governance structure after the IANA transition. Koppell's analysis was undertaken in 2004, after ICANN had been in operation for six years, still having its infancy challenges, and operating under close scrutiny of the US NTIA. In addition to a better mechanism of accountability, ICANN has over the last years strengthened its transparency and allowed stakeholders more influence. ICANN's multistakeholderism is, however, embedded in power asymmetries, and without having mechanisms seeking to reduce these asymmetries, ICANN might be an "instrument of domination by the powerful" (Malcolm, 2016, p. 5).

Moreover, four overarching goals applying to internet governance have been identified: (i) security and stability of the DNS; (ii) open and accessible for all; (iii) diversity and unity; and (iv) safety and security for all. These depend upon a predictable and well-functioning internet governance (Global Commission on Internet Governance, 2016, p. 86).

The successful IANA stewardship transition process does not, however, make a possible UN framework convention on internet governance redundant, as such a process can bring important clarifications, while at the same time facilitating an internet that - with the words of Macron (2018) - is free, open and safe. 


\section{REFERENCES}

Alexy, R. (2000). On the Structure of Legal Principles. Ratio Juris, 13(3), 143-152. https://doi.org/10.1111/1467-9337.00157

Amoretti, F., \& Santaniello, M. (2016). Between Reason of State and Reason of Market: The developments of internet governance in historical perspective. Soft Power, 3(1), 147-167. https://doi.org/10.17450/160109

Appelman, D. L. (2016). Internet governance and human rights. ICANN's transition away from the United States. The Clarion, a journal of the American Bar Association's International Human Rights Committee, 1(1).

Arpagian, N. (2016). The Delegation of Censorship to the Private Sector. In F. Musiani, D.L. Cogburn, L. DeNardis, \& N.S. Levinson (Eds.), The Turn to Infrastructure in Internet Governance (pp. 155-165). Basingstoke: Palgrave Macmillan.

https://doi.org/10.1057/9781137483591_8

Article 19. (2015, June). Issue Report for the Cross Community Working Party on ICANN's Corporate and Social Responsibility to Respect Human Rights: Practical Recommendations for ICANN [Report]. London: Article 19. Retrieved from https://www.article19.org/data/files/medialibrary/38003/ICANN_report_A5-for-web.pdf Association for Progressive Communications (2005, November). APC's Recommendations to the WSIS on Internet Governance. Retrieved from https://www.apc.org/en/pubs/apcsrecommendations-wsis-internet-governance-2005

Brotman, S.N. (2015). Multistakeholder Internet governance: A pathway completed, the road ahead. Washington, DC: The Brookings Institution. Retrieved from https://www.brookings.edu/ /media/research/files/papers/2015/o7/20-multistakeholder-inte rnet-governance-brotman/multistakeholder.pdf

Bygrave, L.B. (2015a). Internet Governance by Contract. Oxford: Oxford University Press. http://doi.org/10.1093/acprof:oso/9780199687343.001.0001

Bygrave, L.B. (2015b). Comment on second draft CCWG proposal. Retrieved from http://forum.icann.org/lists/comments-ccwg-accountability-03aug15/msgooo87.html

Bygrave, L.B. (2009). Introduction. In L.B. Bygrave, \& J. Bing (Eds.), Internet Governance: Infrastructure and Institutions (pp. 1-7). Oxford: Oxford University Press.

https://doi.org/10.1093/acprof:oso/9780199561131.003.0001

Chehadé, F., Akplogan, A.A., Curran, J., Wilson, P.,Housley, R., Arkko, J., St. Amour, L., Echeberría, R., Pawlik, A., \& Jaffe, J. (2013). Montevideo Statement on the Future of Internet Cooperation. Retrieved from https://www.icann.org/news/announcement-2013-10-07-en

Chenou, J.-M. \& Radu, R. (2013). Global Internet Policy: A Fifteen-Year Long Debate. In R. Radu, J.-M. Chenou, \& R. H. Weber (Eds.), Evolution of Global Internet Governance. Principles and Policies in the Making (pp. 3-22). Heidelberg: Springer. https://doi.org/10.1007/978-3-

642-45299-4_1

Cogburn, D.L. (2016). The Multiple Logics of Post-Snowden Restructuring of Internet Governance. In F. Musiani, D.L. Cogburn, L. DeNardis and N.S. Levinson (eds.), The Turn to 
Infrastructure in Internet Governance (pp. 25-45). Basingstoke: Palgrave Macmillan. https://doi.org/10.1057/9781137483591_2

Council of Europe (2019). Committee of Ministers: selection and most recent Adopted Texts. Retrieved from https://www.coe.int/en/web/freedom-expression/committee-of-ministersadopted-texts

Council of Europe (2015). Internet Governance Strategy 2016-2019. Retrieved from https://www.coe.int/en/web/freedom-expression/igstrategy

Council of Europe (2011). Internet Governance - Council of Europe Strategy 2012-2015, $C M(2011) 175$ final.

DeNardis, L. (2014). The Global War for Internet Governance. New Haven; London: Yale University Press.

DeNardis, L. (2013a). The Emerging Field of Internet Governance. In W.H. Dutton (Ed.), The Oxford Handbook of Internet Studies (pp. 555-575). Oxford: Oxford University Press.

DeNardis, L. (2013b) Multi-Stakeholderism: The Internet Governance Challenge to Democracy. Harvard International Review, 34(4), 40-44.

DeNardis, L. (2012). Hidden Levers of Internet Control. An infrastructure-based theory of Internet governance. Information, Communication \& Society, 15(5), 720-738.

https://doi.org/10.1080/1369118X.2012.659199

De Schutter, O., \& Denoble, J. (Eds.) (2010). Reflexive Governance: Redefining the Public Interest in a Pluralistic World. Oxford; Portland: Hart Publishing.

Doria, A. (2013). Use and Abuse of Multitakeholderism in the Internet. In R. Radu, J.-M. Chenou, \& R. H. Weber (Eds.), Evolution of Global Internet Governance. Principles and Policies in the Making (pp. 115-138). Heidelberg: Springer. https://doi.org/10.1007/978-3642-45299-4_7

DotCooperation LLC (n.d.). About .coop. Retrieved from https://www.coop/about_dotcoop European Union. (2015). Regulation (EU) 2015/2120 of the European Parliament and of the Council of 25 November 2015 laying down measures concerning open internet access.

European Union. (2005). Proposal for addition to Chair's paper Sub-Com A internet Governance on Paragraph 5 "Follow-up and Possible Arrangements". Retrieved from https://www.itu.int/net/wsis/docs2/pc3/working/dt21.pdf

Glen, C.M. (2018). Controlling Cyberspace: The Politics of Internet Governance and Regulation Global. Santa Barbara: ABC-CLIO LLC.

Commission on Internet Governance (2016). One Internet. Retrieved from

https://www.ourinternet.org/report

Gurstein, M. (2014, October 19). Democracy OR Multi-stakeholderism: Competing Models of Governance [Blog post]. Gurstein's Community Informatics.

https://gurstein.wordpress.com/2014/10/19/democracy-or-

multi-stakeholderism-competing-models-of-governance 
Hill, R. (2018, February 5). Inside Views: Analysis of The Working Group on Enhanced Cooperation on Public Policy Issues Pertaining to the Internet. Intellectual Property Watch. Retrieved from

http://www.ip-watch.org/2018/o2/o5/analysis-working-group-enhanced-cooperation-public-p olicy-issues-pertaining-internet/

Hill, R. (2013). Internet Governance: The Last Gasp of Colonialism, or Imperialism by Other Means? In R. Radu, J.-M. Chenou, \& R. H. Weber (Eds.), Evolution of Global Internet Governance. Principles and Policies in the Making (pp. 79-94). Heidelberg: Springer.

https://doi.org/10.1007/978-3-642-45299-4_5

Hubbard, A., \& Bygrave, L.B. (2009). Internet governance goes global. In L.B. Bygrave, \& J. Bing (Eds.), Internet Governance: Infrastructure and Institutions (pp. 213-235). Oxford: Oxford University Press. https://doi.org/10.1093/acprof:oso/9780199561131.003.0007 IANA Stewardship Transition Coordination Group (2015). Status of Proposal. Retrieved from https://www.ianacg.org/icg-files/documents/IANA-transition-proposal-v9.pdf

ICANN (2018a, June). CCWG-Accountability WS2 - Final Report [Report]. Los Angeles: Internet Corporation For Assigned Names and Numbers. Retrieved from https://community.icann.org/display/WEIA/WS2+-

+Enhancing+ICANN+Accountability+Home?preview=/59640761/88575033/FULL\%20WS2\% 20REPORT\%20WITH\%20ANNEXES.pdf

ICANN (2018b). ICANN Bylaws, as amended 18 June 2018. Retrieved from https://www.icann.org/resources/pages/governance/bylaws-en

ICANN (2018c). ICANN v. EPAG Domainservices, GmbH.

https://www.icann.org/resources/pages/litigation-icann-v-epag-2018-05-25-en

ICANN (2018d). WS2 - Enhancing ICANN Accountability Home.

https://community.icann.org/display/WEIA/WS2+-

+ Enhancing+ICANN+Accountability+Home

ICANN (2018e). CCWG-Accountability WorkStream2 Activity

Dashboard.

https://community.icann.org/display/WEIA/WS2+Dashboard?preview=/63151029/90767480 /WS2\%20Dashboard\%2OJUN-\%2O20Jul18.pdf.

ICANN (2018f). ICANN Human Rights. https://icannhumanrights.net/documents

ICANN (2018g). ICANN Board Advice Status Report.

https://www.icann.org/resources/files/1214687-2018-03-31-en.

ICANN (2017a). ALAC Statement on the Draft Framework of Interpretation for Human

Rights. AL-ALAC-ST-0617-O1-O1-EN. Retrieved from

https://atlarge.icann.org/en/advice_statements/9985

ICANN (2017b). Summary Report of Public Comment Proceeding [Report]. Los Angeles: Internet Corporation For Assigned Names and Numbers. Retrieved from https://www.icann.org/en/system/files/files/report-comments-foi-hr-o3aug17-en.pdf 
ICANN (2017c). Statement on the Revised ICANN Procedure for Handling WHOIS Conflicts with Privacy Law: Process and Next Steps, AL-ALAC-ST-0717-01-O1-EN. Retrieved from https://atlarge.icann.org/advice_statements/9983

ICANN (2017d). Revised ICANN Procedure for Handling WHOIS Conflicts with Privacy Law. https://www.icann.org/resources/pages/whois-privacy-conflicts-procedure-2008-01-17-en.

ICANN (2017e). About ICANN's Ombudsman. https://www.icann.org/resources/pages/about2012-02-25-en.

ICANN (2016a). CCWG-Accountability Supplemental Final Proposal on Work Stream 1 Recommendations. Retrieved from https://www.icann.org/en/system/files/files/ccwgaccountability-supp-proposal-work-stream-1-recs-23feb16-en.pdf

ICANN (2016b). Amended and Restated Articles of Incorporation of Internet Corporation for Assigned Names and Numbers. https://www.icann.org/resources/pages/governance/articlesen.

ICANN (2015). Ratified: ALAC Statement on the Cross Community Working Group on Enhancing ICANN Accountability 2nd Draft Report (Work Stream 1) [Report]. Los Angeles: Internet Corporation For Assigned Names and Numbers. Retrieved from http://forum.icann.org/lists/comments-ccwg-accountability-03aug15/msgooo96.html.

ICANN (2014a). Call for Public Input: Draft Proposal, Based on Initial Community Feedback, of the Principles and Mechanisms and the Process to Develop a Proposal to Transition NTIA's Stewardship of the IANA Functions. https://www.icann.org/resources/pages/draft-proposal2014-04-08-en.

ICANN (2014b). ALAC Statement on the Proposed Bylaws Changes Regarding Consideration of GAC Advice, AL-ALAC-ST-o914-O1-Oo-EN.

ICANN (2014c). The 2nd At-Large Summit (ATLAS II) Final Declaration, AL-ATLAS-O2DCL-O1-O1-EN.

ICANN (2013, December). Accountability and Transparency Review Team 2. Report and Recommendations [Report]. Los Angeles: Internet Corporation For Assigned Names and Numbers. Retrieved from https://www.icann.org/en/system/files/files/finalrecommendations-31dec13-en.pdf

ICANN (2012). Groups. https://www.icann.org/resources/pages/groups-2012-o2-o6-en

ICANN (2009). Final Declaration, ATLAS I, AL.SUM/GS.02/DOC/02.

ICANN (2002). Advisory: Court Ruling in Auerbach v. ICANN

Lawsuit. https://www.icann.org/news/advisory-2002-07-29-en.

ITEMS International (2017). Final Report [Review of

ICANN's At-Large Community] [Report]. Paris: ITEMS International.

ITU (2012a). Proposals received from ITU Member States for the work of the Conference, Document DT/1-E. Retrieved from www.soumu.go.jp/main_content/ooo188223.pdf 
ITU (2012b). Final Acts, World Conference on International Telecommunications (WCIT-12). Geneva: International Telecommunication Union.

ITU (2005). Global Digital Solidarity Fund inaugurated.

https://www.itu.int/itunews/manager/display.asp?lang=en\&year=2005\&issue=03\&ipage=glob al_digital\&ext=html

ISOC (2015). Perspectives on the IANA Stewardship Transition

Principles.

https://www.internetsociety.org/resources/doc/2015/perspectives-on-the-iana-stewardship-tra nsition-principles

Jamart, A.-C. (2013). Internet Freedom and the Constitutionalization of Internet

Governance. In R. Radu, J.-M. Chenou, \& R.H. Weber (Eds.), Evolution of Global Internet

Governance. Principles and Policies in the Making (pp. 57-76). Heidelberg: Springer.

https://doi.org/10.1007/978-3-642-45299-4_4

Karanicolas, M, \& Kurre, C. (2018, March 14). Cross-Community Working Party on ICANN and Human Rights. ICANN61.

https://static.ptbl.co/static/attachments/169578/1521030196.pdf?1521030196

Koppell, J.G. (2005). Pathologies of Accountability: ICANN and the Challenge of "Multiple Accountabilities Disorder." Public Administration Review, 65(1), 94-108.

https://doi.org/10.1111/j.1540-6210.2005.00434.x

Levinson, N.S., \& Marzouki, M. (2016). International Organizations and Global Internet Governance: Interorganizational Architecture. In F. Musiani, D.L. Cogburn, L. DeNardis, \& N.S. Levinson (Eds.), The Turn to Infrastructure in Internet Governance (pp. 47-71). Basingstoke:

Palgrave Macmillan. https://doi.org/10.1057/9781137483591_3

Macron, E. (2018). IGF 2018 Speech by French President Emmanuel Macron.

https://www.intgovforum.org/multilingual/content/igf-2018-speech-byfrench-president-emmanuel-macron.

Malcolm, J. (2015). Criteria of meaningful stakeholder inclusion in internet governance. Internet Policy Review, 4(4). https://doi.org/10.14763/2015.4.391

Malcolm, J. (2008). Multi-stakeholder Governance and the Internet Governance Forum. Wembley: Terminus Press.

Marby, G. (2018). RE: Request for Guidance: General Data Protection Regulation (GDPR) Impact on the Domain Name System and WHOIS.

https://www.icann.org/en/system/files/correspondence/marby-to-janu-26mar18-en.pdf

Mueller, M. (2016, May 25). The Myth of US Government "Protection" of the Open Internet

[Blog post]. Internet Governance Project, Georgia Tech School of Public

Policy. https://www.internetgovernance.org/2016/o5/25/the-myth-of-usgovernment-protection-of-the-open-internet/

Mueller, M. (2015). The IANA Transition and the Role of Governments in Internet Governance. IP Justice Journal. Retrieved from

http://www.ipjustice.org/wp-content/uploads/2015/09/IPJustice_Journal_Mueller_IANA_Tr 
ansition.pdf

Mueller M. (2010). Networks and States: The Global Politics of Internet

Governance. Cambridge, MA: The MIT Press.

Mueller, M., Mathiason, J., \&Klein, H. (2007). The Internet and Global Governance: Principles and Norms for a New Regime. Global Governance, 13(2), 237-254. Retrieved from

https://www.jstor.org/stable/27800656

NETmundial. (2014). NETmundial Multistakeholder Statement.

http://netmundial.br/wp-content/uploads/2014/o4/NETmundial-Multistakeholder-Document .pdf

NTIA. (2016). Finds IANA Stewardship Transition Proposal Meets Criteria to Complete Privatization. https://www.ntia.doc.gov/press-release/2016/iana-stewardshiptransition-proposal-meets-criteria-complete-privatization

NTIA. (2014). NTIA Announces Intent to Transition Key Internet Domain Name Functions [Press release]. Retrieved from https://www.ntia.doc.gov/press-release/2014/ntia-announcesintent-transition-key-internet-domain-name-functions

OECD. (2011). OECD Guidelines for Multinational Enterprises. Paris: Organisation for Economic Co-operation and Development.

Padovani, C., \& Santaniello, M. (2018). Digital constitutionalism: Fundamental rights and power limitation in the Internet eco-system. International Communication Gazette, 80(4), 295-301. https://doi.org/10.1177/1748048518757114

Padovani, C, Musiani, F., \& Pavan, E. (2010). Investigating Evolving Discourses on Human Rights in the Digital Age. Emerging Norms and Policy Challenges. International Communication Gazette 72(4-5), 359-378. https://doi.org/10.1177/1748048510362618

Pettrachin, A. (2018). Towards a universal declaration on internet rights and freedoms? International Communication Gazette, 80(4), 337-353.

https://doi.org/10.1177/1748048518757139

Raustiala, K. (2017). An Internet Whole and Free. Why Washington Was Right to Give Up Control. Foreign Affairs, 96(2), 140-147.

Raymond, M. (2013) Puncturing the Myth of the Internet as a Commons. Georgetown Journal of International Affairs, 6(1), 53-64. Retrieved from https://www.jstor.org/stable/43134322

Raymond, M., \& DeNardis, L. (2015). Multistakeholderism: anatomy of an inchoate global institution. International Theory, 7(3), 572-616. https://doi.org/10.1017/s1752971915000081

Redeker, D., Gill, L., \& Glasser, U. (2018). Towards digital constitutionalism? Mapping attempts to craft an Internet Bill of Rights. International Communication Gazette, 8o(4), 302-319.

https://doi.org/10.1177/1748048518757121

Ruotolo, G.M. (2017). Fragments of fragments: The domain name system regulation: global law or informalization of the international legal order? Computer Law \& Security Review, 33(2), 159-170. https://doi.org/10.1016/j.clsr.2016.11.007 
Sabatier, P., \& Jenkins-Smith, H.C. (Eds.) (1993). Policy change and learning: An advocacy coalition approach. Boulder, CO: Westview Press.

Scott, B., Heumann, S., \& Kleinhans, J.-P. (2015). Landmark EU and US Net

Neutrality Decisions: How Might Pending Decisions Impact Internet Fragmentation? [Paper No. 18]. Waterloo, Canada; London: Centre for International Governance Innovation \& Chatham House. Retrieved from https://www.cigionline.org/publications/landmark-eu-andus-net-neutrality-decisions-how-might-pending-decisions-impact

G3ict, The Global Initiative for Inclusive ICTs (2009). ICT Accessibility. Self-assessment framework. Fill-in Questionnaire. Retrieved from www.ohchr.org/Documents/HRBodies/CRPD/DGD/2010/G3ictAnnexI.doc

The Verge (2015, February 17). Obama accuses EU of attacking American tech companies because it 'can't compete'. The Verge. Retrieved from

https://www.theverge.com/2015/2/17/8050691/obama-our-companies-created-the-internet

UN (2018). The High-level Panel on Digital Cooperation. https://digitalcooperation.org

UN Development Group (2004). The Human Rights Based Approach. Statement of Common Understanding. https://www.unicef.org/sowco4/files/AnnexB.pdf

UN General Assembly (2019). Advancing responsible State behaviour in cyberspace in the context of international security, A/RES/73/266.

UN General Assembly (2016). Outcome document of the high-level meeting of the General Assembly on the overall review of the implementation of the outcomes of the World Summit on the Information Society, A/RES/70/125.

UN General Assembly (2015). Developments in the field of information and telecommunications in the context of international security, A/RES/70/237.

UN General Assembly (2006). Report of the World Summit on the Information Society, Annex: Tunis Commitment, $A / 60 / 687$.

UN General Assembly (2003). Developments in the field of information and telecommunications in the context of international security, $A / R E S / 58 / 32$.

UN GGE (2015). Group of Governmental Experts on Developments in the field of information and telecommunications in the context of international security, A/70/174.

UN GGE (2013). Group of Governmental Experts on Developments in the field of information and telecommunications in the context of international security, A/68/98.

UN GGE (2010). Group of Governmental Experts on Developments in the field of information and telecommunications in the context of international security, A/65/201.

UN Human Rights Council (2011). Report of the Special Representative on the issue of human rights and transnational corporations and other business enterprises, A/HRC/17/31, Annex [endorsed by A/HRC/RES/17/4].

UN Secretary-General (2018). Address to the Internet Governance

Forum. https://www.un.org/sg/en/content/sg/speeches/2018-11-12/address-internet- 
governance-forum

UN Secretary-General (2017). Group of Governmental Experts on Developments in the field of information and telecommunications in the context of international security, $A / 72 / 327$.

UN WGIG (2005, June). Report of the Working Group on Internet Governance [Report]. Bogis-Bossey: United Nations Working Group on Internet Governance Retrieved from www.wgig.org/docs/WGIGREPORT.pdf

UN WSIS (2003). Declaration of Principles, A/C.2/59/3.

US Government (1998, June 5). Statement of Policy, Management of Internet Names and Addresses, 63 Fed. Reg. 31741 (as amended). Retrieved from

https://www.ntia.doc.gov/federal-register-

notice/1998/statement-policy-management-internet-names-and-addresses

van Schewick, B. (2010). Internet Architecture and Innovation. Cambridge, MA: The MIT Press.

Weber, R.H. (2013). Visions of Political Power: Treaty Making and Multistakeholder Understanding. In R. Radu, J.-M. Chenou \& R. H. Weber (Eds.), Evolution of Global Internet Governance. Principles and Policies in the Making (pp. 95-113). Heidelberg: Springer. https://doi.org/10.1007/978-3-642-45299-4_6

Weber, R. H. (2009). Accountability in Internet Governance. International Journal of Communications Law \& Policy, (13), 152-167.

Weinberg, J. (2012). Non-State Actors and Global Informal Governance - The Case of ICANN. In T. Christiansen, \& C. Neuhold (Eds.), International Handbook on Informal Governance (pp. 292-313). Cheltenham: Edward Elgar. https://doi.org/10.4337/9781781001219.00023

Weinberg, J. (2000). ICANN and the Problem of Legitimacy. Duke Law Journal, 50 (1), 187-260. Retrieved from https://scholarship.law.duke.edu/dlj/vol5o/iss1/5/ 